\title{
PELATIHAN APLIKASI AKUNTANSI BAGI PELAKU USAHA MIKRO, KECIL, DAN MENENGAH DI BANTEN
}

\author{
Kenny Ardillah \\ kenny.ardillah@matanauniversity.ac.id
}

\section{UNIVERSITAS MATANA}

\begin{abstract}
ABSTRAK
Pelatihan aplikasi akuntansi ini ditujukan dalam rangka memberikan pemahaman kepada pelaku usaha dan staf perusahaan untuk dapat menerapkan sistem informasi akuntansi yang memadai dengan menggunakan aplikasi akuntansi untuk sepenuhnya dapat memahami penerapan pencatatan transaksi dan penyajian pelaporan keuangan menggunakan jurnal.id. Lokasi pelatihan aplikasi akuntansi dilakukan di dua tempat usaha pelaku bisnis UMKM di Banten. Pelatihan aplikasi akuntansi dilakukan dengan metode ceramah dan observasi sebanyak 10 sesi pertemuan dalam bulan September 2019 sampai dengan Januari 2020 dengan durasi jam pelatihan untuk setiap sesinya adalah 2 jam. Peserta pelatihan diajarkan modul terkait dengan transaksi pembelian dan penjualan serta pelaporan informasi yang dibutuhkan untuk pelaporan keuangan setiap bulannya. Pelatihan akuntansi berjalan secara efektif dengan kelulusan dari seluruh staf admin atau akuntan yang diperkerjakan oleh pelaku Usaha Mikro, Kecil dan Menengah (UMKM) dalam evaluasi penilaian akhir post test pada akhir sesi pelatihan aplikasi akuntansi. Penulis menyarankan agar pelaku usaha dapat mengalihkan sepenuhnya pencatatan akuntansi secara manual ke pencatatan dengan menggunakan aplikasi akuntansi, sehingga dapat berdampak pada pengoptimalan sistem informasi akuntansi yang memadai untuk mendukung pelaporan kinerja keuangan pelaku Usaha Mikro, Kecil dan Menengah (UMKM) ke depannya.
\end{abstract}

Kata kunci: Pelatihan, Aplikasi Akuntansi, Banten, Pelaku Bisnis, UMKM.

\section{PENDAHULUAN}

Usaha Mikro, Kecil, dan Menengah (UMKM) memiliki peran penting dalam perekonomian masyarakat Indonesia. Usaha Mikro, Kecil, dan Menengah (UMKM) menjadi sector usaha yang menyelematkan perekonomian Indonesia pada saat krisis ekonomi di tahun 1998 dan 2008 (Wardi, et.al, 2018). Pemerintah Indonesia pun memandang penting keberadaan para pelaku UMKM. Sebagai buktinya, UMKM bersama dengan koperasi memiliki wadah secara khusus di bawah Kementerian Koperasi dan Usaha Kecil Menengah.
Perhatian tinggi yang diberikan kepada para pelaku UMKM tersebut tidak lain sebagai wujud pemerintah dalam menyangga ekonomi rakyat kecil. UMKM mampu memberikan dampak secara langsung terhadap kehidupan masyarakat di sektor bawah. Setidaknya, peran UMKM sangat penting dalam kehidupan masyarakat kecil yaitu sebagai sarana mengentaskan masyarakat kecil dari jurang kemiskinan dengan banyaknya penyerapan tenaga kerja yang disumbang oleh Usaha Mikro, Kecil dan Menengah (UMKM). 
Menurut Undang-Undang Nomor 20 Tahun 2008 tentang Usaha Mikro, Kecil dan Menengah (UMKM), usaha mikro adalah usaha produktif milik orang perorangan dan atau badan usaha perorangan yang memenuhi kriteria usaha mikro menurut UU. Usaha kecil adalah usaha ekonomi produktif yang berdiri sendiri, yang dilakukan oleh orang perorangan atau badan usaha yang bukan merupakan anak perusahaan atau bukan cabang perusahaan yang dimiliki, dikuasai, atau menjadi bagian baik langsung maupun tidak langsung dari usaha menengah atau usaha besar yang memenuhi kriteria usaha kecil sebagaimana dimaksud dalam Undang-Undang ini. Usaha menengah adalah usaha ekonomi produktif yang berdiri sendiri, yang dilakukan oleh orang perorangan atau badan usaha yang bukan merupakan anak perusahaan atau bukan cabang perusahaan yang dimiliki, dikuasai, atau menjadi bagian baik langsung maupun tidak langsung dari usaha kecil atau usaha besar yang memenuhi kriteria usaha kecil sebagimana dimaksud dalam UndangUndang ini. Berikut adalah ketentuan pengklasifikasian kategori usaha produktif berdasarkan pembagian lingkup sector usaha yaitu sector usaha mikro, kecil, dan menengah.

Tabel 1. Klasifikasi Kategori Usaha Produktif

\begin{tabular}{|c|c|c|}
\hline $\begin{array}{l}\text { Kategori } \\
\text { Usaha } \\
\text { Produkt } \\
\text { if }\end{array}$ & $\begin{array}{l}\text { Jumlah } \\
\text { Bersih }\end{array}$ & $\begin{array}{l}\text { Jumlah } \\
\text { Penjualan } \\
\text { dalam Setahun }\end{array}$ \\
\hline $\begin{array}{l}\text { Usaha } \\
\text { Mikro }\end{array}$ & $\begin{array}{ll}\leq & \mathrm{Rp} \\
50.000 .000,00\end{array}$ & $\begin{array}{lr}\leq & \mathrm{Rp} \\
300.000 .000,00\end{array}$ \\
\hline $\begin{array}{l}\text { Usaha } \\
\text { Kecil }\end{array}$ & $\begin{array}{l}\text { Rp } \\
50.000 .001,00 \\
\text { s.d } \quad \text { Rp } \\
500.000 .000,00\end{array}$ & $\begin{array}{ll}\mathrm{Rp} & \\
300.000 .001,00 \\
\text { s.d } & \mathrm{Rp} \\
2.500 .000 .000,0 & \\
0 & \end{array}$ \\
\hline $\begin{array}{l}\text { Usaha } \\
\text { Menenga } \\
\mathrm{h}\end{array}$ & $\begin{array}{l}\text { Rp } \\
500.000 .001,00 \\
\text { s.d } \quad \mathrm{Rp} \\
10.000 .000 .000, \\
00\end{array}$ & $\begin{array}{l}\text { Rp } \\
2.500 .000 .001,0 \\
0 \quad \text { s.d } \quad \mathrm{Rp} \\
50.000 .000 .000 \\
00\end{array}$ \\
\hline
\end{tabular}

Berdasarkan data dari Kementerian Koperasi dan UMKM (2018) dalam pelaporan perkembangan data Usaha Mikro, Kecil, Menengah, dan Besar (UMKM) yang terdaftar di Indonesia pada tahun 2016-2017 terdapat perkembangan peningkatan Usaha Mikro, Kecil dan Menengah (UMKM) UMKM sebagai berikut:

Tabel 2. Perkembangan Peningkatan Usaha Mikro, Kecil dan Menengah

\begin{tabular}{|l|l|l|l|}
\hline $\begin{array}{l}\text { Perkembang } \\
\text { an } \\
\text { Peningkatan } \\
\text { UMKM }\end{array}$ & Tahun 2016 & Tahun 2017 & $\begin{array}{l}\text { Peruba } \\
\text { han }\end{array}$ \\
\hline $\begin{array}{l}\text { Jumlah unit } \\
\text { usaha mikro }\end{array}$ & 61.656 .547 & 62.928 .077 & $2,06 \%$ \\
\hline $\begin{array}{l}\text { Jumlah unit } \\
\text { usaha kecil }\end{array}$ & 731.047 & 757.090 & $3,56 \%$ \\
\hline $\begin{array}{l}\text { Jumlah unit } \\
\text { usaha } \\
\text { menengah }\end{array}$ & 56.551 & 58.627 & $3,67 \%$ \\
\hline $\begin{array}{l}\text { Jumlah tenaga } \\
\text { kerja yang } \\
\text { terserap dari } \\
\text { UMKM }\end{array}$ & 112.800 .000 & 120.260 .185 & $6,61 \%$ \\
\hline
\end{tabular}

Berdasarkan hasil pendataan usaha sensus ekonomi 2016 di provinsi Banten diketahui terdapat 20.630 pelaku Usaha Mikro, Kecil dan Menengah (UMKM) di provinsi Banten dengan rincian sebanyak 631 di Pandeglang, 440 di Lebak, 5.962 di Kab. Tangerang, 1.034 di Kab. Serang, 5.473 di Kota Tangerang, 1.334 di Kota Cilegon, 1.254 di Kota Serang, dan 4.502 di Tangerang Selatan. Total pelaku bisnis UMKM terbesar di Banten sebesar 9.266 di sektor usaha perdagangan besar dan eceran, reparasi, dan perawatan mobil dan sepeda motor dengan rincian 419 di Pandeglang, 247 di Lebak, 2.531 di Kab. Tangerang, 487 di Kab. Serang, 2.227 di Kota Tangerang, 549 di Kota Cilegon, 726 di Kota Serang, dan 2.080 di Tangerang Selatan. Dalam hal ini UMKM juga turut memberikan jumlah penyerapan tenaga kerja secara langsung di Banten sebesar 3.349.092 orang. 
Pemerintah bekerja sama dengan perusahaan penyedia jasa marketplace menargetkan sebanyak 8 juta pelaku Usaha Mikro, Kecil dan Menengah (UMKM) untuk dapat merealisasikan program $G o$ Online melalui Gerakan Nasional Ayo UMKM Jualan Online. Hal ini didasarkan dari masih rendahnya penetrasi saluran distribusi Usaha Mikro, Kecil dan Menengah (UMKM) yang hanya mencakup sebesar $7,7 \%$ yang melakukan penjualan secara online di marketplace dari jumlah pelaku Usaha Mikro, Kecil dan Menengah (UMKM) secara keseluruhan di Indonesia sebesar 59,2 juta orang (Kominfo, 2019). Terdapat 3,790.000 pelaku Usaha Mikro, Kecil dan Menengah (UMKM) telah memanfaatkan teknologi digital atau bisnis e-commerce dan kebanyakan pelaku Usaha Mikro, Kecil dan Menengah (UMKM) yang memanfaatkan platform marketplace utama di Tanah Air, seperti Blibli, Tokopedia, Lazada dan Bukalapak (BPS, 2018).

Salah satu permasalahan yang seringkali diabaikan dan tidak diperhatikan oleh para pelaku Usaha Mikro, Kecil dan Menengah (UMKM) dalam pengelolaan bisnisnya yaitu permasalahan pembukuan atau pengelolaan keuangan. Dampak yang dirasakan oleh pelaku Usaha Mikro, Kecil dan Menengah (UMKM) dengan rendahnya kesadaran untuk melakukan pengelolaan keuangan secara efektif belum dirasakan dalam jangka pendek, namun jika pelaku usaha tidak terus-menerus melakukan pengelolaan keuangan dengan menggunakan metode akuntansi secara efektif, maka pelaku Usaha Mikro, Kecil dan Menengah (UMKM) akan kesulitan dalam memahami kinerja bisnisnya secara keseluruhan (Tunggal, 2017). Selain itu, permasalahan pembukuan atau pengelolaan keuangan yang biasanya terjadi di pelaku Usaha Mikro, Kecil dan Menengah (UMKM) adalah tidak adanya pemisahan antara kepemilikan aset pribadi dengan kepemilikan aset yang digunakan dalam pengelolaan usahanya, sehingga seringkali pencatatan akuntansi untuk pengeluaran pribadi dan pengeluaran usaha tidak dipisahkan. Hal ini disebabkan karena sebagian besar pelaku Usaha Mikro, Kecil dan Menengah (UMKM) tidak memiliki latar belakang keahlian akuntansi, sehingga masih kurang memahami pentingnya penggunaan akuntansi dalam menyusun pelaporan keuangan (Wahyuningsih, 2017). Selain itu, pelaku Usaha Mikro, Kecil dan Menengah (UMKM) juga memiliki keterbatasan finansial dalam mempekerjakan seorang akuntan yang memiliki latar belakang keahlian akuntansi untuk melakukan pencatatan dan penyusunan pelaporan keuangan (Dahlan, et.al, 2018).

Teknologi informasi yang semakin berkembang dengan pesat telah memberikan perubahan yang signifikan dalam kepentingan usaha untuk seluruh lingkup kategori pada saat ini, termasuk dalam lingkup kategori Usaha Mikro, Kecil dan Menengah (UMKM) (Ria, 2018). Teknologi akuntansi menjadi kebutuhan yang diperlukan saat ini untuk memberikan dukungan bagi pencatatan akuntansi bagi pelaku Usaha Mikro, Kecil dan Menengah (UMKM). Teknologi akuntansi menjadi perwujudan sistem informasi dalam menghasilkan informasi keuangan yang dapat digunakan oleh pihak-pihak yang berkepentingan dalam menganalisis aktivitas ekonomi dan kondisi perusahaan berdasarkan hasil proses siklus akuntansi yang disajikan dalam laporan keuangan (Rudianto, 2012).

Sistem informasi akuntansi yang biasanya menjadi kebutuhan dalam pelatihan pelaku Usaha Mikro, Kecil dan Menengah (UMKM) adalah sistem informasi yang bersifat pengguna tunggal. Sistem informasi akuntansi dengan pengguna tunggal dapat digunakan untuk memenuhi kebutuhan informasi akuntansi pelaku usaha yang memerlukan akses informasi akuntansi. Sistem informasi akuntansi perlu mengkombinasikan berbagai komponen sistem informasi seperti sumber daya manusia yang dapat menjalankan sistem yang dapat dengan cepat mengambil keputusan dan 
mengendalikan pengoperasian, prosedur penerapan sistem informasi yang menjadi acuan dalam menjalankan pengoperasian, data yang merupakan unsur pokok untuk mencatat semua transaksi yang terjadi, software yang merupakan fasilitas yang dirancang secara terkomputerisasi dalam memproses data perusahaan, dan infrastruktur teknologi informasi yang merupakan peralatan berbasis teknologi dalam memproses data yang di dalamnya adalah komputer, peralatan pendukung, dan peralatan komunikasi jaringan (Romney dan Steinbart, 2014).

Dalam pembuatan laporan keuangan pada pelaku Usaha Mikro, Kecil dan Menengah (UMKM), perlu dipersiapkan bukti transaksi yang dikumpulkan untuk dijadikan data akuntansi yang direkap untuk dilakukan pencatatan dalam bentuk jurnal. Jurnal yang sudah dicatat akan dikumpulkan untuk membentuk laporan keuangan yang sudah terotomatisasi pada aplikasi akuntansi yang memudahkan penilaian pihak lain maupun internal perusahaan dalam menentukan kinerja bisnisnya dalam tahun berjalan. Oleh sebab itu, kontribusi perlu dilakukan untuk membantu pelaku bisnis di Banten dalam mendukung perkembangan bisnis melalui sistem informasi akuntansi yang memadai melalui penggunaan aplikasi akuntansi jurnal.id. Pelatihan aplikasi akuntansi ini diharapkan dapat membantu pelaku usaha Usaha Mikro, Kecil dan Menengah (UMKM) di Banten untuk memberikan pemahaman kepada pelaku usaha dan staf perusahaan untuk dapat menerapkan sistem informasi akuntansi yang memadai dengan menggunakan aplikasi akuntansi untuk sepenuhnya dapat memahami penerapan pencatatan transaksi dan penyajian pelaporan keuangan menggunakan jurnal.id.

\section{METODE KEGIATAN}

Kegiatan pelatihan aplikasi akuntansi berfokus di beberapa unit usaha mikro, kecil dan menengah yang sudah merupakan subjek pajak baik perorangan dan berbadan usaha CV yang berlokasi di Kelurahan Kelapa Dua yang termasuk di Kabupaten Tanggerang di propinsi Banten. Perusahaan yang disasar menjadi target pelatihan aplikasi akuntansi adalah perusahaan yang bergerak di bidang perdagangan besar dan eceran yang penjualannya dilakukan secara konvensional dan daring menggunakan media e-commerce dengan memiliki toko penjualan fisik dan daring serta memiliki reputasi penjual yang positif.

Kegiatan pelatihan aplikasi akuntansi pelaku Usaha Mikro, Kecil dan Menengah (UMKM) dilakukan oleh dosen akuntansi Universitas Matana di dua lokasi usaha pelaku Usaha Mikro, Kecil dan Menengah (UMKM) di Gading Serpong dan Cibodas dari tanggal 4 September 2019 - 22 Januari 2020. Namun di bulan Agustus 2020, penulis melakukan kunjungan survey ke masingmasing lokasi usaha pelaku Usaha Mikro, Kecil dan Menengah (UMKM) dan melakukan observasi pemantauan selama setengah hari atas seluruh pengoperasian pencatatan akuntansi perusahaan. Durasi jam pelatihan aplikasi akuntansi untuk setiap sesi pertemuan pada dua lokasi usaha pelaku Usaha Mikro, Kecil dan Menengah (UMKM) selama 1-2 jam. Total durasi sesi pertemuan yang dihabiskan penulis untuk mengadakan pelatihan aplikasi akuntansi selama 24 jam yang mencakup total sesi pertemuan untuk survei dan wawancara dengan pelaku bisnis di lokasi usaha pelaku Usaha Mikro, Kecil dan Menengah (UMKM) selama 4 jam dan total sesi 10 kali pelatihan di lokasi usaha pelaku bisnis selama 20 jam.

Pelaku bisnis Usaha Mikro, Kecil dan Menengah (UMKM) yang menjadi subjek pelatihan aplikasi akuntansi ini adalah Jonathan yang merupakan pemilik toko daring penjualan perlengkapan rumah tangga dan Christopher pemilik toko daring di bidang otomotif. Kedua pelaku bisnis Usaha Mikro, Kecil dan Menengah (UMKM) ini merupakan wirausahawan yang masih berusia muda di bawah 30 tahun dan sudah merintis usaha toko daring dan offline selama beberapa tahun dan telah 
memiliki omset rata-rata per bulan sebesar Rp 200.000.000. Pendapatan yang mereka peroleh sangat bergantung pada kondisi bisnis secara siklikal yang menyebabkan omset usaha yang mereka peroleh tidak menentu setiap bulannya. Hal ini juga berdampak pada alokasi pengeluaran yang harus mereka rencanakan setiap bulannya.

Aplikasi akuntansi yang diajarkan oleh penulis dalam pelatihan aplikasi akuntansi yang menunjang sistem informasi akuntansi pelaku Usaha Mikro, Kecil dan Menengah (UMKM) di Banten adalah Jurnal.id. Jurnal.id merupakan perangkat lunak akuntansi online yang aman dan andal digunakan bagi pelaku Usaha Mikro, Kecil dan Menengah (UMKM) di Indonesia. Aplikasi akuntansi tersebut dapat memberikan kemudahan dalam memecahkan persoalan administrasi dan operasional keuangan dan perpajakan, sehingga pelaku Usaha Mikro, Kecil dan Menengah (UMKM) dapat berfokus kepada hal-hal terpenting lainnya dalam mengembangkan bisnis mereka. Jurnal.id dapat diakses di mana saja dengan menggunakan koneksi internet atau WiFi. Jurnal.id menggunakan teknologi cloud yang menjadikan terobosan terbaru dalam dunia teknologi di bidang akuntansi. Kelebihan yang dimiliki oleh jurnal.id dibandingkan aplikasi akuntansi lainnya yaitu dapat memudahkan proses pencatatan keuangan secara otomatis tanpa menggunakan bahasa akuntasi yang rumit, membuat faktur penjualan, pesanan pembelian, dan surat jalan secara otomatis dan menyiapkan laporan keuangan secara instan hanya dengan sekali klik, dan data keuangan perusahaan dapat diakses secara real time dan dapat dijamin keamanannya karena data tersimpan di host server jurnal.id.

Pelatihan aplikasi akuntansi diterapkan secara teoritis dan praktikal yang ditujukan kepada karyawan pelaku bisnis yang berwenang sebagai staf akuntansi atau staf keuangan dan bagian administrasi yang berwenang melakukan pencatatan transaksi pembelian dan penjualan secara harian dan mempersiapkan laporan keuangan setiap bulannya. Pemberian konsep teori dilakukan dengan menggunakan metode ceramah yaitu pemateri memberikan pengarahan dan peserta mendengarkan. Pelaksanaan pelatihan aplikasi akuntansi juga dilakukan melalui observasi praktik dalam memberikan pemahaman dan mengaplikasikan fitur yang terdapat pada aplikasi akuntasi jurnal.id, penginputan transaksi keuangan dan aspek perpajakannya ke dalam jurnal, penyiapan laporan piutang dan hutang usaha, dan penyiapan laporan keuangan.

Perserta pelatihan aplikasi akuntansi dituntut untuk berpartisipasi secara aktif dalam berinteraksi dan bertanya secara langsung selama pengajar memberikan penjelasan dan praktik pelatihan aplikasi akuntansi sesuai dengan permasalahan yang dihadapi oleh pelaku bisnis pada sistem informasi akuntansi perusahaan. Evaluasi dilakukan di sesi akhir pelatihan yang mana pengajar memberikan tes kepada peserta pelatihan untuk menganalisa seberapa baik peserta pelatihan telah memahami seluruh materi pelatihan yang diajarkan dari awal hingga akhir sesi pelatihan. Jika semua peserta sudah mendapatkan nilai yang memadai untuk standar kelulusan, maka peserta akan diberikan bukti keikutsertaan pelatihan. Di akhir sesi, peserta pelatihan juga diberikan kuesioner yang wajib diisi sebagai permintaan umpan balik dari peserta pelatihan terkait pemenuhan hasil yang diharapkan selama sesi pelatihan dari segi pengajaran, penilaian manfaat dan kebutuhan yang berasal dari materi pelatihan, dan suasana serta ketepatan waktu dalam pemberian materi dan pelaksanaan sesi pelatihan. Keseluruhan materi pelatihan yang diajarkan pengajar diberikan di akhir pertemuan kepada peserta pelatihan untuk dapat dipelajari atau direview kembali oleh peserta pelatihan untuk membantu peserta pelatihan dalam mengaplikasikan materi pelatihan aplikasi akuntansi pada penerapan dan pengembangan sistem informasi akuntansi bisnis pelaku Usaha Mikro, Kecil dan Menengah (UMKM). 


\section{HASIL DAN LUARAN}

Di bulan Agustus 2019, penulis telah melakukan kunjungan survey dan pendekatan kepada pelaku Usaha Mikro, Kecil dan Menengah (UMKM) melalui wawancara untuk memahami permasalahan sistem informasi akuntansi akuntansi yang dihadapi pelaku bisnis. Mikro, Kecil dan Menengah (UMKM) yang menjadi subjek pelatihan aplikasi akuntansi yang masih menggunakan pencatatan secara manual menggunakan Microsoft Excel. Bagi pelaku Usaha Mikro, Kecil dan Menengah (UMKM) yang belum menggunakan pencatatan akuntansi dengan menggunakan aplikasi akuntansi, maka penulis sudah meminta pelaku usaha untuk menggunakan aplikasi akuntansi jurnal.id dalam penerapan sistem informasi akuntansi usaha mereka dengan melakukan instalasi program aplikasi jurnal.id pada beberapa komputer yang dioperasikan staf perusahaan dengan installer dasn lisensi trial yang sudah disediakan penulis.

Pelaku Usaha Mikro, Kecil dan Menengah (UMKM) yang menjadi sasaran subjek pelatihan aplikasi akuntansi ini mengakui masih belum sepenuhnya menginvestasikan sepenuhnya keuntungan usaha yang mereka peroleh untuk menerapkan sistem informasi akuntansi yang memadai dikarenakan pelaku bisnis perlu mengeluarkan biaya maintenance per tahun dan memberikan pelatihan secara berkala kepada karyawan dalam penggunaan aplikasi akuntansi seiring dengan adanya pembaruan versi aplikasi akuntansi setiap tahunnya. Selain itu, karena karyawan yang dipekerjakan belum menguasai fitur pada aplikasi akuntansi, maka pelaku Usaha Mikro, Kecil dan Menengah (UMKM) meyakini adanya kesalahan pada pencatatan yang diinput di aplikasi akuntansi dapat terjadi yang menyebabkan efek domino berantai yang berdampak pada kesalahan di tahapan siklus akuntansi selanjutnya yang membuat penyajian pelaporan keuangan yang salah. Hal ini yang membuat pencatatan transaksi masih dilakukan secara konvensional melalui penginputan secara manual di Microsoft Excel dengan tetap mengikuti kaidah tahapan pada siklus akuntansi yang digambarkan sebagai berikut.

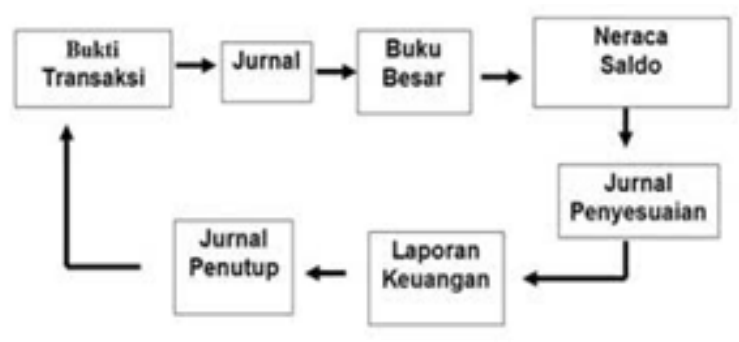

Gambar 1. Siklus Akuntansi

Proses pencatatan transaksi dan pelaporan keuangan pada pelaku Usaha Mikro, Kecil dan Menengah (UMKM) yang menjadi sasaran pelatihan aplikasi akuntansi ini sudah diterapkan sesuai dengan siklus akuntansi yang dimulai dari pengumpulan dokumen pendukung yang sudah diverifikasi yang transaksinya akan dicatat ke dalam jurnal dan diposting ke dalam buku besar berdasarkan setiap penomoran akun yang sudah dibuat sebelumnya. Setelah direkap secara bulanan dalam buku besar, maka proses pengikhtisaran dilakukan berdasarkan nilai akun yang sudah terakumulasi secara bulanan diperbarui di neraca saldo perusahaan. Pada akhir bulan, staf administrasi atau akuntan dapat membuat jurnal penyesuaian bila diperlukan dan jurnal penutup untuk dibuat neraca saldo setelah penutup. Setelah itu, proses pelaporan dapat dilakukan dengan menyiapkan laporan keuangan yang terdiri dari laporan laba rugi dan laporan posisi keuangan.

Selama sesi pelatihan pertama sampai dengan ketiga, penulis membekali peserta pelatihan dengan penjelasan awal untuk memahami gambaran secara nyata kelebihan pencatatan dan pelaporan keuangan menggunakan aplikasi akuntansi dibandingkan dengan pencatatan dan pelaporan secara manual. Berikut adalah kelebihan jika pelaku Usaha Mikro, Kecil dan Menengah (UMKM) melakukan pencatatan menggunakan software aplikasi 
akuntansi dibandingkan melakukan pencatatan secara manual.

1. Melakukan pengolahan data secara lebih cepat, sehingga pelaku usaha dapat mengambil keputusan dalam menentukan perencanaan bisnis ke depan dalam waktu yang lebih cepat.

2. Memberikan informasi akuntansi yang menyeluruh dengan tingkat privasi dan keamanan yang terjamin yang dapat membantu perusahaan dalam merumuskan berbagai kebijakan.

3. Memberikan kemudahan dan efisiensi waktu dalam merekrut sumber daya manusia yang diperlukan sesuai kebutuhan pelaku usaha karena hanya memerlukan satu orang untuk menginput data dan mengoperasikan sistem informasi akuntansi.

4. Memberikan kemudahan akses kepada pelaku usaha karena sistem informasi akuntansi dapat diakses oleh pelaku usaha secara real time, sehingga pelaku usaha dapat mengontrol posisi keuangan serta laba rugi yang diperoleh pelaku usaha dalam periode harian, mingguan, bulanan, dan bahkan tahunan.

Peserta pelatihan juga diberikan penjelasan untuk memahami seberapa jauh pemahaman peserta pelatihan terkait dengan fitur-fitur yang penting digunakan dalam pencatatan dan pelaporan keuangan menggunakan jurnal.id. Fitur-fitur yang dimiliki oleh jurnal.id yang disorot dalam materi pelatihan ini selain modul setting pembelian dan penjualan yang menjadi fokus utama dari pemberian pelatihan ini adalah modul bank, pajak, dan kurs. Pada sesi pelatihan ini, peserta pelatihan diperkenalkan modul bank, pajak, dan kurs ini agar peserta pelatihan dapat mengenal adanya laporan rekonsiliasi bank dan laporan mutasi rekening, ringkasan bank dan pengakuan laba rugi selisih pertukaran mata uang asing yang terealisasi dan tidak terealisasi serta laporan pajak pemotongan dan penjualan yang belum digunakan oleh mereka dalam penerapan siklus akuntansi saat ini.
Pada sesi pelatihan keempat sampai ketujuh, peserta pelatihan diajarkan cara melakukan penginputan dan pencatatan transaksi pembelian, penjualan, serta penerimaan dan pengeluaran kas atau bank. Pada sesi pelatihan kedelapan dan kesembilan, peserta pelatihan diajarkan cara menyajikan keseluruhan transaksi pembelian dan penjualan yang sudah dicatat dalam bentuk laporan pembelian dan laporan penjualan. Pada sesi pelatihan kesepuluh yang merupakan sesi terakhir, peserta diberikan praktik untuk menampilkan laporan keuangan dalam periode bulanan dan tahunan.

Peserta pelatihan juga diwajibkan mengikuti post test dengan waktu pengerjaan selama 30 menit agar pengajar materi dapat memahami sejauh mana peserta pelatihan memahami materi pelatihan yang dipaparkan dari awal hingga akhir sesi pelatihan. Peserta pelatihan diwajibkan mendapatkan nilai minimum sebesar 70 dari 100 untuk mendapatkan pencapaian lulus dan kesemua peserta pelatihan sudah mencapai nilai minimum kelulusan dari post test yang telah dilakukan di akhir sesi pelatihan. Peserta pelatihan juga diwajibkan memberikan umpan balik dengan mengisi kuesioner evaluasi keseluruhan kegiatan pengabdian kepada masyarakat berupa pelatihan akuntansi yang diberikan dari sesi pertama hingga sesi kesepuluh. Skor yang diberikan dari setiap kuesioner yang dibagikan ke masing-masing peserta pelatihan memuaskan dengan pencapaian indikator rata-rata sangat setuju dari penilaian pembicara, materi, dan suasana. Peserta pelatihan memberikan penilaian sangat baik atas penyampaian materi oleh penulis, metode ceramah dan diskusi yang dibawakan penulis dengan suasana kondustif dan berlangsungnya sesi pelatihan secara kondusif dan tepat waktu, dan adanya manfaat dan peningkatan pengetahuan dan keahlian yang dapat diperoleh dari sesi pengajaran penggunaan aplikasi akuntansi ini.

Perserta pelatihan juga diberikan materi pelatihan dari awal hingga akhir sesi 
pelatihan untuk membantu peserta pelatihan dapat mereview materi bagi pelaku Usaha Mikro, Kecil dan Menengah (UMKM) yang belum menggunakan aplikasi akuntansi dan mengevaluasi kembali permasalahan yang dihadapi dalam sistem informasi akuntansi bagi pelaku Usaha Mikro, Kecil dan Menengah (UMKM) yang sudah menggunakan aplikasi akuntansi. Berikut adalah ikhtisar materi pelatihan yang dibagikan selama sesi pelatihan aplikasi akuntansi dan evaluasi sebelum dan sesudah pelatihan aplikasi akuntansi yang dirangkum penulis pada karyawan dan pelaku Usaha Mikro, Kecil dan Menengah (UMKM) yang belum melakukan pencatatan transkasi dengan menggunakan aplikasi akuntansi yang sebagian besar berfokus pada transaksi pembelian dan penjualan yang merupakan transaksi dengan porsi terbesar bagi toko online di marketplace.

Tabel 3. Materi Pelatihan Aplikasi Akuntansi

\begin{tabular}{|c|c|c|}
\hline $\begin{array}{l}\text { Topik } \\
\text { Pelatihan }\end{array}$ & $\begin{array}{l}\text { Observasi } \\
\text { Sebelum } \\
\text { Pelatihan }\end{array}$ & $\begin{array}{l}\text { Evaluasi } \\
\text { Setelah } \\
\text { Pelatihan }\end{array}$ \\
\hline $\begin{array}{l}\text { Input } \\
\text { Transaksi } \\
\text { Pemesanan } \\
\text { Penjualan }\end{array}$ & $\begin{array}{l}\text { Peserta } \\
\text { pelatihan } \\
\text { belum } \\
\text { melengkapi } \\
\text { semua } \\
\text { informasi } \\
\text { yang } \\
\text { diperlukan } \\
\text { untuk } \\
\text { dimasukkan } \\
\text { dalam } \\
\text { penginputan } \\
\text { pemesanan } \\
\text { penjualan. }\end{array}$ & $\begin{array}{l}\text { Peserta } \\
\text { pelatihan } \\
\text { sudah } \\
\text { melengkapi } \\
\text { semua } \\
\text { informasi } \\
\text { yang } \\
\text { diperlukan } \\
\text { untuk } \\
\text { dimasukkan } \\
\text { dalam } \\
\text { penginputan } \\
\text { pemesanan } \\
\text { penjualan } \\
\text { dan } \\
\text { memahami } \\
\text { sepenuhnya } \\
\text { penggunaan } \\
\text { fitur } \\
\text { pemesanan } \\
\text { penjualan. }\end{array}$ \\
\hline $\begin{array}{l}\text { Input } \\
\text { Konfirmasi }\end{array}$ & $\begin{array}{l}\text { Peserta } \\
\text { pelatihan }\end{array}$ & $\begin{array}{l}\text { Peserta } \\
\text { pelatihan }\end{array}$ \\
\hline
\end{tabular}

\begin{tabular}{|c|c|c|}
\hline $\begin{array}{l}\text { Pengiriman } \\
\text { atas } \\
\text { Pesanan } \\
\text { Penjualan } \\
\text { yang Sudah } \\
\text { Dibayar }\end{array}$ & $\begin{array}{l}\text { belum } \\
\text { memasukkan } \\
\text { data pesanan } \\
\text { penjualan } \\
\text { dan } \\
\text { pengiriman } \\
\text { secara } \\
\text { lengkap dan } \\
\text { tidak } \\
\text { menggunaka } \\
\text { n fitur } \\
\text { konfirmasi } \\
\text { pengiriman } \\
\text { ini. }\end{array}$ & $\begin{array}{l}\text { sudah } \\
\text { memasukka } \\
\mathrm{n} \text { sebagian } \\
\text { data pesanan } \\
\text { penjualan } \\
\text { dan seluruh } \\
\text { informasi } \\
\text { pengiriman } \\
\text { secara } \\
\text { lengkap dan } \\
\text { dapat } \\
\text { memahami } \\
\text { sepenuhnya } \\
\text { penggunaan } \\
\text { fitur } \\
\text { konfirmasi } \\
\text { pengiriman } \\
\text { untuk setiap } \\
\text { pesanan } \\
\text { penjualan. }\end{array}$ \\
\hline $\begin{array}{l}\text { Input } \\
\text { Transaksi } \\
\text { Penagihan } \\
\text { Penjualan }\end{array}$ & $\begin{array}{l}\text { Peserta } \\
\text { pelatihan } \\
\text { belum } \\
\text { memasukkan } \\
\text { data pesanan } \\
\text { penjualan } \\
\text { secara } \\
\text { lengkap dan } \\
\text { tidak } \\
\text { menggunaka } \\
\text { n fitur } \\
\text { penagihan } \\
\text { penjualan ini. }\end{array}$ & $\begin{array}{l}\text { Peserta } \\
\text { pelatihan } \\
\text { sudah } \\
\text { memasukka } \\
\text { n sebagian } \\
\text { data pesanan } \\
\text { penjualan } \\
\text { dan dapat } \\
\text { memahami } \\
\text { sepenuhnya } \\
\text { penggunaan } \\
\text { fitur } \\
\text { penagihan } \\
\text { penjualan. }\end{array}$ \\
\hline $\begin{array}{l}\text { Terima } \\
\text { Pembayara } \\
\text { n Transaksi } \\
\text { Penjualan }\end{array}$ & $\begin{array}{l}\text { Peserta } \\
\text { pelatihan } \\
\text { belum } \\
\text { memasukkan } \\
\text { data } \\
\text { informasi } \\
\text { pembayaran } \\
\text { secara } \\
\text { lengkap. }\end{array}$ & $\begin{array}{l}\text { Peserta } \\
\text { pelatihan } \\
\text { sudah } \\
\text { memasukka } \\
\mathrm{n} \quad \text { data } \\
\text { informasi } \\
\text { pembayaran } \\
\text { secara } \\
\text { lengkap dan } \\
\text { dapat } \\
\text { memahami } \\
\text { sepenuhnya } \\
\text { pengunaan } \\
\text { fitur } \\
\text { pembuatan }\end{array}$ \\
\hline
\end{tabular}




\begin{tabular}{|c|c|c|}
\hline & & $\begin{array}{l}\text { pembayaran } \\
\text {. }\end{array}$ \\
\hline $\begin{array}{l}\text { Input } \\
\text { Transaksi } \\
\text { Pemesanan } \\
\text { Pembelian }\end{array}$ & $\begin{array}{l}\text { Peserta } \\
\text { pelatihan } \\
\text { belum } \\
\text { melengkapi } \\
\text { semua } \\
\text { informasi } \\
\text { yang } \\
\text { diperlukan } \\
\text { untuk } \\
\text { dimasukkan } \\
\text { dalam } \\
\text { penginputan } \\
\text { pemesanan } \\
\text { pembelian. }\end{array}$ & $\begin{array}{l}\text { Peserta } \\
\text { pelatihan } \\
\text { sudah } \\
\text { melengkapi } \\
\text { semua } \\
\text { informasi } \\
\text { yang } \\
\text { diperlukan } \\
\text { untuk } \\
\text { dimasukkan } \\
\text { dalam } \\
\text { penginputan } \\
\text { pemesanan } \\
\text { pembelian } \\
\text { dan } \\
\text { memahami } \\
\text { sepenuhnya } \\
\text { fitur dalam } \\
\text { menu } \\
\text { pemesanan } \\
\text { pembelian. }\end{array}$ \\
\hline $\begin{array}{l}\text { Input } \\
\text { Konfirmasi } \\
\text { Pengiriman } \\
\text { atas } \\
\text { Tagihan } \\
\text { Pembelian } \\
\text { yang Sudah } \\
\text { Dibayar }\end{array}$ & $\begin{array}{l}\text { Peserta } \\
\text { pelatihan } \\
\text { belum } \\
\text { memasukkan } \\
\text { data pesanan } \\
\text { pembelian } \\
\text { dan } \\
\text { pengiriman } \\
\text { secara } \\
\text { lengkap dan } \\
\text { tidak } \\
\text { menggunaka } \\
\text { n fitur } \\
\text { konfirmasi } \\
\text { pengiriman } \\
\text { ini. }\end{array}$ & $\begin{array}{l}\text { Peserta } \\
\text { pelatihan } \\
\text { sudah } \\
\text { memasukka } \\
\text { n sebagian } \\
\text { data pesanan } \\
\text { pembelian } \\
\text { dan seluruh } \\
\text { informasi } \\
\text { pengiriman } \\
\text { secara } \\
\text { lengkap dan } \\
\text { dapat } \\
\text { memahami } \\
\text { sepenuhnya } \\
\text { penggunaan } \\
\text { fitur } \\
\text { konfirmasi } \\
\text { pengiriman } \\
\text { ini untuk } \\
\text { setiap } \\
\text { pesanan } \\
\text { pembelian. }\end{array}$ \\
\hline $\begin{array}{l}\text { Input } \\
\text { Penagihan } \\
\text { Pembelian }\end{array}$ & $\begin{array}{l}\text { Peserta } \\
\text { pelatihan } \\
\text { belum } \\
\text { memasukkan }\end{array}$ & $\begin{array}{l}\text { Peserta } \\
\text { pelatihan } \\
\text { sudah } \\
\text { memasukka }\end{array}$ \\
\hline
\end{tabular}

\begin{tabular}{|c|c|c|}
\hline & $\begin{array}{l}\text { data pesanan } \\
\text { pembelian } \\
\text { secara } \\
\text { lengkap dan } \\
\text { tidak } \\
\text { menggunaka } \\
\text { n fitur } \\
\text { penagihan } \\
\text { pembelian } \\
\text { ini. }\end{array}$ & $\begin{array}{l}\text { n sebagian } \\
\text { data pesanan } \\
\text { pembelian } \\
\text { dan dapat } \\
\text { memahami } \\
\text { sepenuhnya } \\
\text { penggunaan } \\
\text { fitur } \\
\text { penagihan } \\
\text { pembelian } \\
\text { ini. }\end{array}$ \\
\hline $\begin{array}{l}\text { Input } \\
\text { Pembayara } \\
\text { n Tagihan } \\
\text { Pembelian }\end{array}$ & $\begin{array}{l}\text { Peserta } \\
\text { pelatihan } \\
\text { belum } \\
\text { memasukkan } \\
\text { data } \\
\text { informasi } \\
\text { pembayaran } \\
\text { secara } \\
\text { lengkap. }\end{array}$ & $\begin{array}{l}\text { Peserta } \\
\text { pelatihan } \\
\text { sudah } \\
\text { memasukka } \\
\text { n data } \\
\text { informasi } \\
\text { pembayaran } \\
\text { secara } \\
\text { lengkap dan } \\
\text { dapat } \\
\text { memahami } \\
\text { sepenuhnya } \\
\text { penggunaan } \\
\text { fitur } \\
\text { pengajuan } \\
\text { permohonan } \\
\text { pembayaran }\end{array}$ \\
\hline $\begin{array}{l}\text { Pencatatan } \\
\text { Biaya }\end{array}$ & $\begin{array}{l}\text { Peserta } \\
\text { pelatihan } \\
\text { belum } \\
\text { memasukkan } \\
\text { akun biaya di } \\
\text { daftar akun } \\
\text { dan belum } \\
\text { memiliki } \\
\text { histori } \\
\text { pencatatan } \\
\text { biaya di } \\
\text { menu biaya. }\end{array}$ & $\begin{array}{l}\text { Peserta } \\
\text { pelatihan } \\
\text { sudah } \\
\text { memasukka } \\
\text { n akun biaya } \\
\text { di daftar } \\
\text { akun dan } \\
\text { dapat } \\
\text { memahami } \\
\text { sepenuhnya } \\
\text { penerapan } \\
\text { pencatatan } \\
\text { sebagian } \\
\text { besar biaya } \\
\text { yang diakui } \\
\text { dalam } \\
\text { periode } \\
\text { berjalan di } \\
\text { menu biaya. }\end{array}$ \\
\hline $\begin{array}{l}\text { Pembayara } \\
\text { n biaya }\end{array}$ & $\begin{array}{l}\text { Peserta } \\
\text { pelatihan }\end{array}$ & $\begin{array}{l}\text { Peserta } \\
\text { pelatihan }\end{array}$ \\
\hline
\end{tabular}




\begin{tabular}{|c|c|c|}
\hline & $\begin{array}{l}\text { belum } \\
\text { memasukkan } \\
\text { akun biaya di } \\
\text { daftar akun } \\
\text { dan belum } \\
\text { memasukkan } \\
\text { informasi } \\
\text { pembayaran } \\
\text { biaya. }\end{array}$ & $\begin{array}{l}\text { sudah } \\
\text { memasukka } \\
\mathrm{n} \text { akun biaya } \\
\text { di daftar } \\
\text { akun dan } \\
\text { dapat } \\
\text { memahami } \\
\text { sepenuhnya } \\
\text { penerapan } \\
\text { pencatatan } \\
\text { sebagian } \\
\text { besar biaya } \\
\text { yang diakui } \\
\text { dalam } \\
\text { periode } \\
\text { berjalan } \\
\text { untuk } \\
\text { dibayarkan } \\
\text { berdasarkan } \\
\text { informasi } \\
\text { pembayaran } \\
\text { yang sudah } \\
\text { dimasukkan } \\
\text { di menu } \\
\text { biaya. }\end{array}$ \\
\hline $\begin{array}{l}\text { Penyajian } \\
\text { laporan } \\
\text { Penjualan }\end{array}$ & $\begin{array}{l}\text { Peserta } \\
\text { pelatihan } \\
\text { belum } \\
\text { mengetahui } \\
\text { adanya fitur } \\
\text { laporan yang } \\
\text { dapat } \\
\text { menyajikan } \\
\text { laporan } \\
\text { penjualan. }\end{array}$ & $\begin{array}{l}\text { Peserta } \\
\text { pelatihan } \\
\text { sudah } \\
\text { memahami } \\
\text { sepenuhnya } \\
\text { penyajian } \\
\text { laporan } \\
\text { penjualan di } \\
\text { menu } \\
\text { laporan ini. }\end{array}$ \\
\hline $\begin{array}{l}\text { Penyajian } \\
\text { Laporan } \\
\text { Pembelian }\end{array}$ & $\begin{array}{l}\text { Peserta } \\
\text { pelatihan } \\
\text { belum } \\
\text { mengetahui } \\
\text { adanya fitur } \\
\text { laporan yang } \\
\text { dapat } \\
\text { menyajikan } \\
\text { laporan } \\
\text { pembelian. }\end{array}$ & $\begin{array}{l}\text { Peserta } \\
\text { pelatihan } \\
\text { sudah } \\
\text { memahami } \\
\text { sepenuhnya } \\
\text { penyajian } \\
\text { laporan } \\
\text { pembelian } \\
\text { di menu } \\
\text { laporan ini. }\end{array}$ \\
\hline
\end{tabular}

Sumber : Diambil Dari Jurnal.id Dan Dibuat Penulis

\section{KESIMPULAN}

Berdasarkan hasil evaluasi dari kegiatan pelatihan aplikasi akuntansi yang sudah penulis adakan di lokasi usaha pelaku bisnis Usaha Mikro, Kecil dan Menengah (UMKM) di Banten maka dapat penulis dapat memberikan kesimpulan sebagai berikut:

1. Staf admin atau akuntan yang diperkerjakan oleh pelaku Usaha Mikro, Kecil dan Menengah (UMKM) lulus dalam evaluasi penilaian akhir post test pada akhir sesi pelatihan dan dapat memulai menggunakan aplikasi akuntansi untuk pencatatan transaksi dan mengalihkan pencatatan data transaksi yang masih dicatat secara manual dengan menggunakan Microsoft Excel ke penggunaan aplikasi akuntansi. Penulis menyarankan agar pelaku usaha dapat mengalihkan sepenuhnya pencatatan akuntansi secara manual ke pencatatan dengan menggunakan aplikasi akuntansi jurnal.id, sehingga dapat berdampak pada pengoptimalan sistem informasi akuntansi yang memadai untuk mendukung pelaporan kinerja keuangan Usaha Mikro, Kecil dan Menengah (UMKM) ke depannya.

2. Perlunya infrastruktur yang memadai bagi pelaku Usaha Mikro, Kecil dan Menengah (UMKM) dalam menerapkan sistem informasi akuntansi yang menunjang aktivitas pencatatan transaksi yang berhubungan dengan pendapatan dan pengeluaran usaha dengan memanfaatkan fitur pembelian dan penjualan yang terdapat pada aplikasi akuntansi jurnal.id seperti penginputan transaksi penjualan dan pembelian, konfirmasi penerimaan pesanan pembelian dan pengiriman atas pesanan penjualan yang dibayar, dan penagihan pembelian dan penjualan yang berdampak pada perolehan dan pengeluaran di akun kas dan bank. Penulis menyarankan agar pelaku Usaha Mikro, Kecil dan Menengah (UMKM) dapat mengalokasikan biaya investasi yang lebih besar dalam membeli lisensi 
penggunaan aplikasi akuntansi untuk dapat menunjang pengembangan sistem informasi akuntansi yang menunjang peningkatan kinerja keuangan Usaha Mikro, Kecil dan Menengah (UMKM).

\section{DAFTAR PUSTAKA}

Badan Pusat Statistik Provinsi Banten. (2018). Hasil Pendataan Usaha Perusahaan Sensus Ekonomi 2016Lanjutan Provinsi Banten.

Bappeda Kabupaten Tangerang. (2017). RKPD Kabupaten Tangerang Tahun 2017. Diakses tanggal 7 Agustus 2019 dari tangerangkab.com/wp-

http://bappedacontent/uploads/mdocs/bab\%20II.pdf

Dahlan, T., Murfiah, U dan Indriani, R. (2018). Pelatihan Pembukuan Sederhana bagi UKM Kerajinan Anyam Pandan di Kecamatan Rajapolah, Tasikmalaya. Jurnal Solma, Vol. 7, No. 2.

Jurnal.id. (2019). Buku Panduan Jurnal.id. Diakses tanggal 8 Agustus 2019 dari https://www.jurnal.id/id/guidebooks.

Kementerian Koperasi dan UMKM. (2018). Perkembangan Data Usaha Mikro, Kecil, dan Menengah (UMKM) dan Usaha Besar (UB) Tahun 2016-2017. Diakses tanggal 8 Agustus 2019 dari http://www.depkop.go.id/uploads/lap oran/1549946778_UMKM\%2020162017\%20rev.pdf.

Kominfo. (2019). UMKM Go Online. Diakses tanggal 1 September 2020 dari

https://www.theindonesianinstitute.co $m / w p-$

content/uploads/2018/10/PaparanUMKM-versi-1.1.pdf.

Kontan. (2018). Jumlah Pelaku UMKM di 2018 Diprediksi Mencapai 58,97 Juta Orang. Diakses tanggal 8 Agustus 2019 dari https://keuangan.kontan.co.id/news/ju mlah-pelaku-umkm-di-2018diprediksi-mencapai-5897-jutaorang.
Republik Indonesia. (2008). UndangUndang Nomor 20 Tahun 2008 tentang Usaha Mikro, Kecil dan Menengah (UMKM).

Ria, A. (2018). Analisis Penerapan Aplikasi Keuangan Berbasis Android pada Laporan Keuangan UMKM Mekarsari, Depok. Sosio e-kons, Vol. 10, No. 3, pp. 207-219.

Romney, M. B dan P. J. Steinbart. (2014). Sistem Informasi Akuntansi Edisi Ketiga Belas. Jakarta : Salemba Empat.

Rudianto. (2012). Pengantar Akuntansi. Jakarta: Penerbit Erlangga.

Solopos. (2018). Pemerintah Dorong Pembukuan UMKM lewat Aplikasi. Diakses tanggal 8 Agustus 2019 dari https://soloraya.solopos.com/read/20 181025/490/948306/pemerintahdorong-budaya-pembukuan-umkmlewat-aplikasi.

Tunggal, Cahyani Sari dan Etty Indriani. (2017). Pentingnya Pembukuan Sederhana Bagi Kelompok UMKM KUB Murakabi Desa Ngaryoso. Jurnal Pengabdian Pada Masyarakat Wasana Nyata, Vol. 1, No 1.

Wahyuningsih, D. E, I. Setiawati, dan T. A. Prasojo. (2017). Pemberdayaan Pelaku Usaha Mikro Dengan Memberikan Pelatihan Pembukuan Sederhana di Desa Bangunrejo Kecamatan Patekebon Kabupaten Kendal. Prosiding Seminar Nasional Publikasi Hasil-Hasil Penelitian dan Pengabdian Masyarakat Universitas Muhammadiyah Semarang.

Wardi, Jeni, Liviawati, dan Putri, G.E. (2017). IBM UKMK di Bidang Akuntansi dan keuangan Desa di Kecamatan Bunut Kabupaten Pelalawan Provinsi Riau, Indonesia. Dinamisia: Jurnal Pengabdian Kepada Masyarakat, Vol. 1, No. 1, pp. 29-34. 